\title{
STRATEGIC COST MANAGEMENT FOR CONSTRUCTION PROJECT SUCCESS: A SYSTEMATIC STUDY
}

\author{
T. G. K. Vasista \\ Ph D Research Scholar \\ SunRise University, Alwar
}

\begin{abstract}
Large construction projects are inherently complex and dynamic. Many projects start with good ideas, huge investments and great efforts. However, most of them do not achieve much success. A major contribution to unsuccessful projects is the lack of understanding on scope, time, cost and quality. Projects as powerful strategic weapons when initiated create economic value and competitive advantage. The objective of the research is to explicitly declare the scope of the research to by considering only the scope, time, cost and quality as process success parameters and how specifically the cost element would influence the project success when all other elements or factors other than cost are represented in terms of cost factor along with the contract conditions as basic rules or constraints that drive the strategic cost based on applying the CRASP methodology concept. The concept of benchmarking would provide right meaning of project success when allowing to properly distributing the meaning of customer profitability to the project providers (project owner and contractors).
\end{abstract}

\section{KEYWORDS}

Cost Management, Strategic Cost Management, Project Cost Management, Project Management Benchmarking, Project Success.

\section{INTRODUCTION}

Large construction projects are inherently complex and dynamic (Nguyen, Ogunlana \& Lan, 2004). Many projects start with good ideas, huge investments and great efforts. However, most of them do not achieve much success. A major contribution to unsuccessful projects is the lack of understanding on project definition and its scope. A properly defined and managed scope leads to delivering quality project in agreed cost and within specified schedules to the stake-holders. Project scope deals with the required work to create the project deliverables. The scope of the project is specific to the work required to complete the project objectives (Mirza, Pourzolfaghar \& Shahnazari, 2013). Projects as powerful strategic weapons when initiated create economic value and competitive advantage. Defining and assessing project success is therefore a strategic management concept that can align project efforts with short-term and long-term goals of the organization. Traditionally projects were perceived as successful when they meet time, budget and performance goals (Shenhar, Dvir, Levy \& Maltz, 2001). Therefore project success has been a central topic in the project management literature (Handfield, Primo \& de Oliveira, 2015).

Project Success can be defined as meeting goals and objectives as prescribed in the project plan. A successful project means that the project has accomplished its technical performance (quality cost), maintained its schedule and remained within budgetary cost (Frimpong, Oluwoye \& Crawford, 2003). 
A project can be considered to be the achievement of a specific objective, which involves a series of activities and tasks which consume resources. It has to be completed within a set of specification, having definite start and end dates (Munns \& Bjeirmi, 1996).

According to BS6079 Guide to project Management, A project can be stated as a unique set of coordinated activities with definite starting and finishing points, undertaken by an individual or organization to meet specific objectives within defined schedule, cost and performance parameters (Lester, 2013).

A project management can be defined as the process of controlling achievement of the project objectives. The function of a project management is to define the requirements of work, extensions, resource allocation, planning the execution of work, progress monitoring and adjusting the deviations from the plan. It uses organizational structures, resources, tools and techniques to achieve the project success without adversely affecting the routing operations of the company (Munns \& Bjeirmi, 1996).Project management is essentially management of change, while running a functional or ongoing business is managing a continuum or business-as-usual (Lester, 2013).

However, in this paper, the definition as mentioned in Atkinson (1999) has been adopted. "Project Management is the application of a collection of tools and techniques to direct the use of diverse resources toward the accomplishment of a unique, complex, one-time task within time, cost, and quality constraints. Each task requires a particular mix of these tools and techniques structured to fit the task environment and life cycle (from the conception to completion) of the task".

While the goal of the research is to achieve project success, the objective of the research is to explicitly declare the scope of the research to by considering only the scope, time, cost and quality as process success parameters and how specifically the cost element would influence the project success when all other elements or factors other than cost are represented in terms of cost factor along with the contract conditions as basic rules or constraints that drive the strategic cost based on applying the CRASP methodology concept. The concept of benchmarking would provide right meaning of project success when allowing to properly distributing the meaning of customer profitability to the project providers (project owner and contractors).

\section{LITERATURE SURVEY}

A Literature Review on what is project success has been done by Prabhakar (2008). The research work performed by Chan (2001) leaded by Sidwell at Queensland University of Technology, Australia, describes various the project success model of Shenhar et al. (1997), Atkinsons'(1999) model of measuring project success, the macro and micro view of project success as given by Lim \& Mohamed (1999). Further Eight (8) factors have been mentioned as Key Performance Indicator (KPIs) characteristics for achieving project success. They are Quality, cost, time, safety, participant satisfaction, user satisfaction, environmental performance, commercial/profitable value etc.The research Project done by Olaoluwa (2013) at Federal University of Technology in Nigeria is having good qualitative material that has become useful content in terms of obtaining definitions related to cost and cost and project management. 
A systematic review of factors influencing the cost performance of building projects is done by Odediran \& Wndapo (2014), where the authors have focused and presented the literature review on the issue of cost overruns and its various incidents and also tabulated the top rated factors that are influencing cost over runs on construction projects ranging during the period of 19972013.Research on cost performance for building construction projects in Klang Valley, Malaysia is done by Ali \& Kamaruzzaman (2010). The study between time-cost relationships in Australian Building Construction Projects is done by Peter E. D. Love; Raymond Y. C. Tse; and David J. Edwards during the year 2005, where it is shown that Gross Floor Area and number of stories in a building are key determinants of time performance and cost performance.

Spreng and Mackoy (1996) model of service performance that leads to assess service quality to finally measure customer satisfaction could become a potentially useful model when properly customized to forecast and measure project quality cost (AlSudairi, 2005). Spreng and Mackoy (1996) structurally validated the Oliver's model (1993) of service quality and the results confirmed that service quality is antecedent to customer satisfaction. In fact Olver's model is tested in the case of a construction project where it was found that service incidents, service quality and customer satisfaction wre linked at eah stage of constrution (Forsythe, 2015).

Vasista \& Al-Sudairi (2016) have developed the Beh-Act approach to project management success viewing through the CRASP methodology that is applicable to construction industry. Their approach can very well gives the research progress and status explaining through stages in deductive process. Though Safety is one of the project success factors indicated in the research, in this paper the scope has been made limited by not discussing the safety but discussing only the strategic perspective of cost management and how it influences the project success.

Therefore, while the fundamental aim and goal of the research is to work for the project success model, however the objective of the research is to explicitly declare the scope of the research to by considering only the scope, time, cost and quality as process success parameters and how specifically the cost element would influence the project success when all other elements or factors other than cost are represented in terms of cost factor along with the contract conditions as basic rules or constraints that drive the strategic cost.

\section{LITERATURE REVIEW}

\subsection{Scope of the Project Success Considered}

The role of project management is to use the resources available effectively to accomplish a goal that is set within certain criteria (Munns \& Bjeirmi, 1996). Criteria are the set of principles or standards by which judgment is made; whereas factors are the set of circumstances, facts or influences which contribute to the result. Two broad criteria to determine the macro viewpoint of project success are: completion and satisfaction (Lim \& Mohammed, 1999).

According to Rad \& Levin (2002), Project success indicators are: (i) Things related (ii) People related. While completion could be things related, satisfaction is people related. In this paper the project success indicators have been dealt with things related only i.e. scope, quality(or technical design \&quality), schedule and cost. 


\subsection{Relationship between Time, Cost\& Scope in project Success}

A project has a definite starting and finishing point and must meet certain specified objectives. Broadly these objectives are required to be achieved by meeting three fundamental criteria i.e.: (i) the project must be completed on time (ii) the project must be accomplished within the budgeted cost and (iii) the project must meet the prescribed quality requirements. These criteria can be graphically represented by well-known project triangle (Lester, 2013).

Referring to the Figure 1, the Triple constraints in project management for successfully completing and closing the project are: Scope/Quality, Schedule/Time and Cost/Resource, where Time: Refers to the actual time required to produce a deliverable. Cost is the estimation of the amount of money that will be required to complete the project and the Scope aspect of the project is its inherent quality upon the delivery (Tomtsongas, 2011).

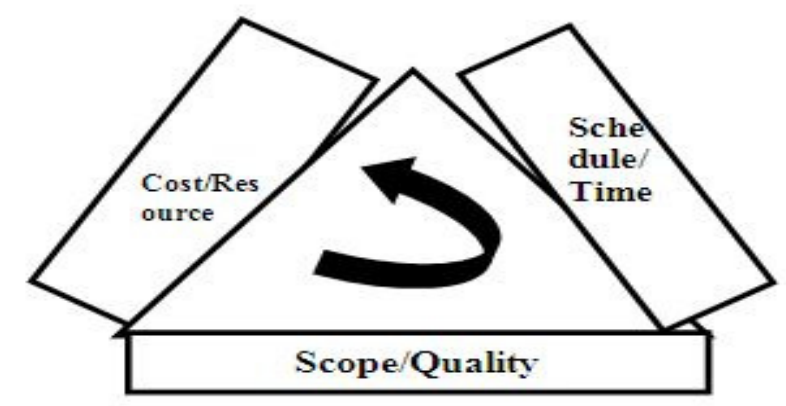

Fig.1. Triple Constraints in Project Management (Source: Tomtsongas, 2011).

Project success has to consider the multi-dimensional constraint criteria such as not just the triple constraint as shown in Fig. 1, but could consider the project management hexagon with six constraints such as scope, quality, risk, customer satisfaction, time and cost in passing (Tomtsongas, 2015).

\subsection{Principal and Common Causes of Project Delays}

There are five principal and common causes of delays. They are: (i) poor site management and supervision (ii) unforeseen ground conditions (iii) low speed of decision making involving all project teams (iv) Client initiated variations and (v) necessary variations of works. Therefore it is important to construct a construction time forecasting model to minimize delays (Chan \& Kumaraswamy, 1997). However a detailed literature review study on causes of delay in building construction projects is done by Pethkar \& Birajdar (2014).

\subsection{Project Cost Management and Control}

Cost means expenses incurred by contractor for labor, material, services, utilities etc., plus overheads and contractor's profits. Cost Management is the process by which costs (expenses) incurred on a project are formally identified, approved and paid. Cost control is the deliberations, actions and reactions to project cost fluctuations during a project to maintain the project cost within the project budget (Olaoluwa, 2013). Cost management is the process of controlling the expenditure on a construction project at all stages from initiation to completion, within the approved budget (Young \& Ibbs, 2002). Cost performance is a measure of efficiency expenses 
spent on project. Cost performance is measured by cost performance index (CPI) which is a measure of the cost efficiency with which the project is being performed. CPI is function of cumulative earned value and cumulative actual cost (Olaoluwa, 2013). Cost management process involves different stages: (i) initial stage, (ii) planning stage (iii) execution stage (iv) controlling stage and (v) completion stage (DoF, 2009).

Project cost management includes the processes required to ensure that the project is completed within the approved budget. There are three fundamental elements in cost management. The cost management includes the processes involved in (i) cost estimating, cost budgeting and cost controlling costs so that the project can be completed within the approved budget (Owens, Burke, Krynovich \& Mance, 2009). It also includes resource planning, which includes determining what resources (people, equipment, materials) and what quantities of each should be used to perform project activities (PMBOK, 1996). For this purpose project managers must make sure that their projects are well defined, have accurate time and cost estimates and have a realistic budget involved in approving. Costs are usually measured in monetary units like the national currency such as Dollars, Rupees, and Riyals etc. (Jainendrakumar, 2015).

Cost control is basic to managerial accounting. Schedule control is more recent phenomenon entered into project management concept. Integration of schedule and cost control has been becoming a natural objective of project control systems since late 1970s (Carr, 1990).

\subsection{Project Control Indicators}

Three of the four highlighted constraints have been discussed below as mentioned bin Chan (2001) in passing.

Time: Time is the duration for completing the project. It is scheduled to enable the building to be used by a date determined by the client's future plans. Construction Time is the absolute time that is calculated as the number of days/weeks from start on site to practical completion of the project

i.e. Construction time $=$ Practical Completion Date - project Commencement Date

Time Variation $=(($ Construction Time- Revised Contract Period $) /$ Revised Contract Period $) * 100$

Where Revised contract period = original contract period + EOT .

Cost:Cost is an important measure and is defined as the degree to which the general conditions promote the completion of a project within the estimated budget. Cost is usually confined to the sum quoted in tender documents. It is the overall cost that a project incurs from inception to completion. So it includes any costs that arise from variations, modifications during construction period and the cost created by the legal claims, such as litigation and arbitration. The measure of the cost can be in the form of unit cost, percentage of net variation over final cost.

Unit cost $=$ Final contract sum/ Gross Floor Area $(\mathrm{m} 2)$

$\%$ NETVAR $=($ Net value of variations/Final Contract Sum $) * 100 \%$

Where net value of variations $=$ Final contract sum-base

Base $=$ Original contract sum + Final Rise and Fall - Contingency Allowance. 
Quality and Scope are important intangible measures. Quality deals with the measure of technical specification, it means to what extent the technical requirements specified can be achieved. Freeman and Beale (1992) extended the definition of technical performance with scope and quality. Therefore meeting technical specification is grouped under the quality category (Chan, 2001).

Quality is defined as the totality of features and inherent or assigned characteristics of a product, process, service and/or system that bear on its ability to show that it meets expectations or satisfies stated needs, requirements or specifications.Scope is the total aggregation of deliverables to be produced by the project. A deliverable is a quantifiable outcome of a project which results in the partial (or full) achievement of cost budgeting, project objectives (Olaoluwa, 2013).

Schedule analysis and forecasting and cost analysis forecasting are the two major project control indicators considered to achieve project managementefficiency, which in turn refers to: schedule variance, schedule performance index, time estimate at completion, cost variance, cost performance index and are given as follows (Tom \& Paul, 2013).

\section{(i) Schedule Analysis and Forecasting}

Schedule variance (SV): It determines whether a project is behind or ahead of the schedule. It is calculated by subtracting planned value from the earned value.

Schedule variance $=$ Earned value $(\mathrm{EV})-$ Planned value $(\mathrm{PV})$; when schedule variance is expressed in percentage as $\mathrm{SV} \%=\mathrm{SV} / \mathrm{PV}$

Where Earned Value is a technique for measuring project performance according to both project cost and schedule. The technique compares the budgeted cost of the work to the actual costSchedule Performance Index (SPI): It indicates efficiency with which the project team is using its time.

Schedule Performance Index = Earned value/Planned value

Time Estimate at Completion $\{\mathrm{EAC}(\mathrm{t})\}$ : A rough estimate $\mathrm{f}$ when a project can be completed can be generated. $\{\mathrm{EAC}(\mathrm{t})\}=\{(\mathrm{BAC} / \mathrm{SPI}) /(\mathrm{BAC} /$ months $)$

$\mathrm{BAC}=$ Budget at Completion.

\section{(ii) Cost Analysis and Forecasting}

Cost Variance $(\mathrm{CV})$ : It shows whether a project is under or over budget.

Cost Variance $(\mathrm{CV})=$ Earned Value $(\mathrm{EV})$ - Actual Cost $(\mathrm{AC})$. This number can be expressed as a percentage as $\mathrm{CV} \%=\mathrm{CV} / \mathrm{EV}$

Cost Performance Index (CPI): It is one of the clearest indicators of the cumulative cost efficiency of the project. CPI = Earned Value (EV)/Actual Cost $(\mathrm{AC})$.

\section{(iii) Technical Performance and Forecasting}

A technical performance tracking system can be developed by systematically studying the cost of quality. Quality can be defined as conformance to requirements (Davis, Ledbetter \& Burati Jr., 1989). Quality costs are estimated up to $20-40 \%$ of its revenue (Crosby, 1979). 
PMI (2000) definition of cost of quality can be expressed as the whole effort to acquire the quality of deliverables and these efforts include work needed by requirements and rework.

Quality control cost included in costs of construction projects is the costs required by related regulation and contract conditions for achieving quality of contractual object (Song \& Lee, 2004). The cost of quality can be measured in two parts: (i) cost of quality management efforts and (ii) cost of correcting deviations or variance (Davis, Ledbetter \& Burati Jr., 1989).

According to Rosenfeld (2009), Cost of Quality (COQ) conformance as a "quality" expenses and COQ nonconformance as "non-quality" expenses (Barlow, 2009), where conformance costs are the costs for achieving satisfactory quality. Conformance costs include prevention costs and appraisal costs. Non-conformance costs are the costs originated from low quality level and are composed of internal-failure costs and external costs (Song \& Lee, 2004).

In cinch, the Cost of Quality (COQ) can be broken down into four main categories under two broad categories: 1. Conformance Quality Cost: (i) Prevention Cost (ii) Appraisal cost2. Nonconformance quality cost: (iii) Internal Failure (iv) External Failureand are defined as follows (Barlow, 2009; Song \& Lee, 2004):

Prevention costs are incurred by contractor for activities which are undertaken to prevent internal or external non-conformance issues Barlow, 2009). Simply, it is the cost arising from prevention measures, which includes cost related to education, planning etc. (Song \& lee, 2004).

Appraisal costs are incurred by the contractor in the process of conducting inspections, making evaluations and collecting data (Barlow, 2009). Simply it is the cost related to performing check on deliverables (products and services). It includes the cost for conducting inspection, lab test, on-site test etc. (Song \& Lee, 2004).

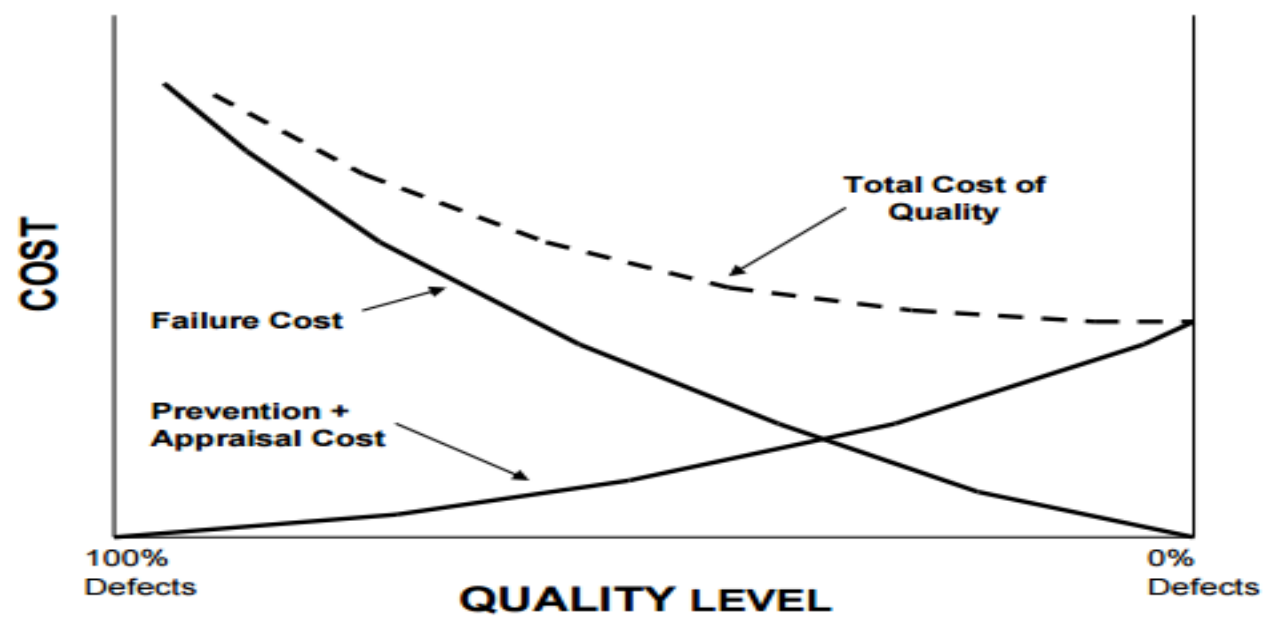

Fig.2. Cost Versus Quality Level (Source: Barlow, 2009)

Internal Failure costs are incurred upon the contractor due to unsatisfactory results prior to the owner's acceptance of the building-failure (Barolow, 2009). Simply it the cost related to 
resolving problems prior to delivery of product to customer. It includes the cost related to disposal, re-production, stand-by etc. (Song \& Lee, 2004).

External failure costs incur upon the contractor when poor quality is discovered after the owner accepts the building -defect (Barlow, 2009). Simply it is the cost related to solving customer claims in connection with deliverables such as products or services. It includes the cost related to maintaining quality assurance, exchange, refund etc. (Song \& Lee, 2004).

Therefore now it is also important to include the quality cost into project cost control managerial accounting.

\subsection{Relating quality cost with schedule and cost}

Quality cost is used as an indicator to evaluate quality performance and influences company's financial performance. To achieve the goal of the quality control in construction projects, factors such as quality, schedule, and cost should be considered to achieve project success (Song \& Lee, 2004).

\section{PROJECT COST MANAGEMENT TOOLS AND TECHNIQUES}

The capabilities of tools and techniques refer to: Expert judgment, Analogous estimating, Parametric estimating, Bottom-up estimating, Three-point estimates, Reverse analysis, Cost of quality, Project management estimating software and Vendor bid analysis (Rajabi, Undated).Project control automation and relationships of project control to project integrated data bases have been explored earlier. Project Management Software such as Primavera (Tom \& Paul, 2013) and MS Project (Jainendrakumar, 2015) describes detailed cost and schedule integration with a focus on exception reporting (Carr, 1990).

\section{RESEARCH MODEL PROPOSED \& HYPOTHESIS DEVELOPMENT}

The discussion for the research question: what is project success and what is the impact of standard form contracts on it has been worked by Chan, Coffey \& Trigunarsyah (2010). In their research the mentioned that according to Sanvido et al. (1992, 94-111), project success is understood as the degree to which project goals and expectations are met. Though they included technical, financial, educational, social and professional aspects, in the current research the scope has been limited to consider technical and financial aspect only. Further, the research of Chan, Coffey and Trigunarsyah (2010) also planned to study how contract conditions influence or impact project success (or failure).

The study of contract conditions in project management and project success is important because, contracts set the basic playing rules for the project. Theoretically speaking, both parties freely enter the contract to create optimal conditions for successfully completing the project. Practically speaking, contract is often seen as a competitive game, in which the objective is to place the other party at a disadvantage, especially if things go badly (Stevens, 2009-2011). 


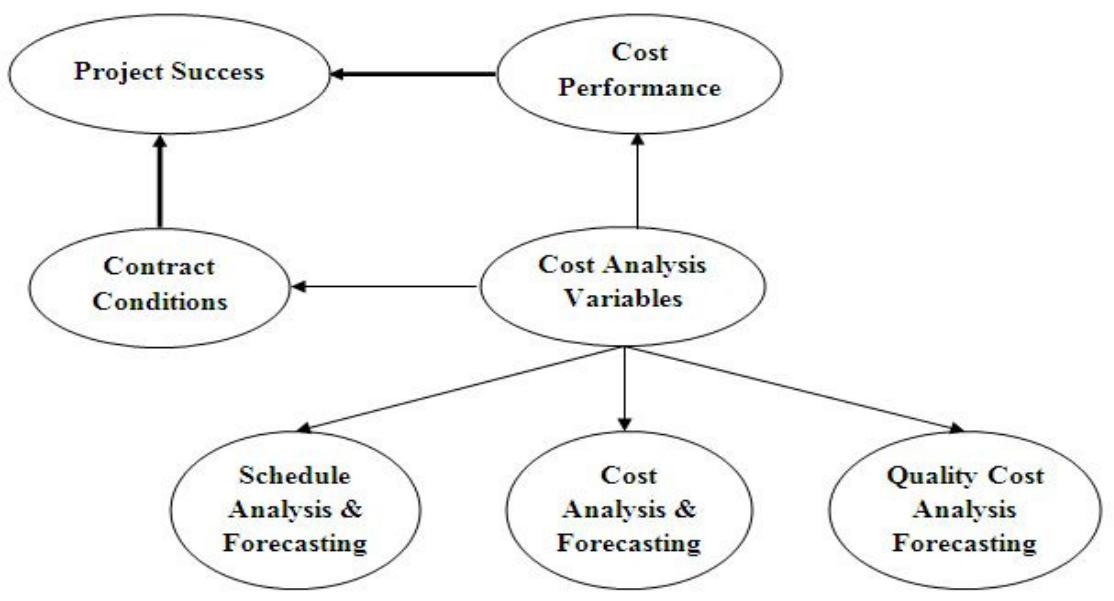

Fig. 3. Project Success Research Model focusing on cost performance scope- Proposed

While most of the literature on project success indicated project cost performance as one of the main key performance indicators, from the perspective of applying CRASP methodology (Vasista, ALSudairi, 2016), it is important to discuss the concept of Benchmarking. Takim \& Akintoye $(2002,547)$ has brought the discussion on "Benchmarking". CBPP (Construction Best Practice Programme) defines benchmarking as a systematic process of comparing and measuring the performance of the companies (business activities) against others and using lessons learned from the best to make targeted improvements. While KPI is the measure of the performance of the process that is critical to its success. The best performance achieved in practice is the benchmark. The objective of benchmarking is to understand the existing processes and activities and then to identify an external point of reference or standard by which that activity can be measured or judged. A comprehensive model that would bring and transforms KPIs would result the prediction of project success through project performance are: (i) effectiveness and (ii) efficiency (Takin \& Akintoye, 2002). While efficiency is understood as the collection of objective measures (e.g. cost performance), the effectiveness (e.g. contract conditions) is the collection of subjective measures.

Correspondingly, the relationship between project success, cost performance and contract conditions can be depicted as shown in the figure 4 .

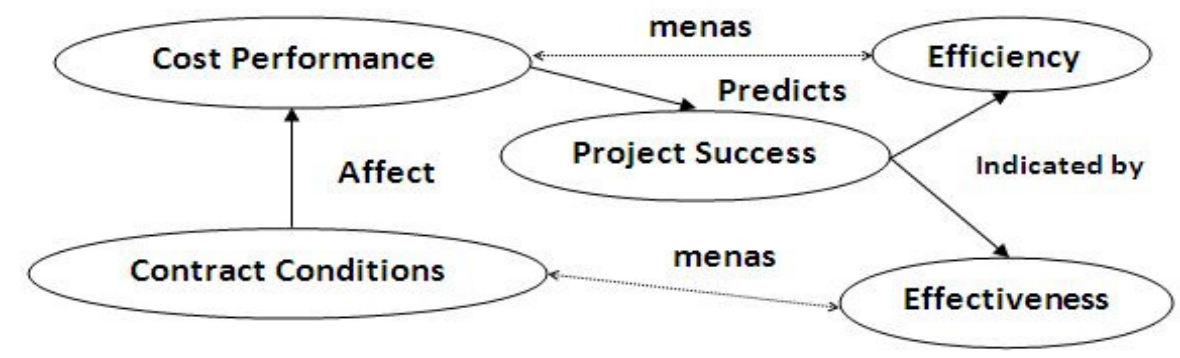

Fig. 4 Project Success Research Model focusing on project success- Proposed (Influenced by both cost performance and contract conditions)

\section{Research Hypothesis:}

H1: Contract conditions affect cost performance 
$\mathrm{H} 2$ : Cost performance predicts project success

H3: Cost performance means achieving project efficiency

H4: Contract conditions means achieving project effectiveness

\section{DISCUSSION AND CONCLUSION}

In the customer-focused paradigm, high quality deliverables can strengthen competitiveness, raise market-share and provide basis for long-term relationship with owners. But in most cases, lack of quantitative data makes it difficult for managers to judge the current status of although quality based technical performance is one of the critical success factors for evaluating a construction project success; there is no practical guideline for measuring such intangibles. Therefore in this paper an attempt is made to measure and analyze the quality cost towards indicating the evaluation of technical performance in project management in construction projects. Quality cost can play an intermediate role in project management from a cost perspective and consequently contributes to the success of the construction project (Song \& Lee, 2004).

From the above discussion it is evident that the research model of project success is a function of project efficiency and project effectiveness which are further mapped and represented in terms of cost performance and contract conditions respectively in order to meet the project scope and definitions. Now it is important to bring all different kinds of costs as objective measures and such measure when get subjected to the constraints mentioned in contract conditions would indicate the degree of project success. In this regard the cost-time relationship and cost-quality relationship and the basic scope of the construction project are and their applicability is defined in the contract document as conditions. Such contract document serves as business rules.

\section{FUTURE RESEARCH}

While cost performance could be obtained both objectively and subjectively by transforming quality cost also into its objective equivalents, however assessing how contract conditions influences the project success along with the cost performance is a typical study that reflects more a subjective study. Therefore it is important to see how a systematic study can be conducted to interlink the study of benchmarking and. contract conditions towards leading to project success. It is also important to further study by dividing the cost performance from the perspective of customer and provider to decide the optimal point of project profitability. Therefore applying and viewing CRASP methodology would essentially keep the project to analyze it to derive the scope of conducting cost-benefit analysis by properly tuning the project success. Further, based on the CRASP methodology framework for benchmarking construction project development that could reasonably considers the stakeholders' objectives, expectations and priorities for the project. 
Civil Engineering and Urban Planning: An International Journal (CiVEJ ) Vol.4, No.1, March 2017

\section{REFERENCES}

[1] Ali, A. S. \& Kamaruzzaman, S. N. (2010). Cost of Performance for building construction projects in Klang Valley. Journal of Building Performance, 1(1), 110-118.

[2] AlSudairi, M. A. T. (2012). E-Service Quality Strategy: Achieving Customer Satisfaction in Online Banking. Journal of Theoretical and Applied Information Technology. 2 (38), 6-24.

[3] Atikinson, R. (1999). Project management: cost, time and quality two best guesses and a phenomenon, it's time to accept other success criteria. International Journal of Project Management, 19 (6), 337-342.

[4] Atkinson, R. (1999). Project management: cost, time and quality, two best guesses and a phenomenon, it's time to accept other success criteria. International Journal of Project Management, 17(6), 337-342, Pergamon.

[5] Barlow, P. (2009). Cost of Quality in the Construction Industry. [Online] URL:http://digitalcommons.calpoly.edu/cgi/viewcontent.cgi?article $=1009 \&$ context=cmgt_fac Retrieved on May 28, 2016.

[6] Carr, R. I. (1992). Cost, Schedule and Time Variances and Integration. Journal of Construction Engineering and Management, 245-265, ASCE

[7] Chan, D. WM. \& Kumaraswamy, M. M., (1997). A comparative study of causes of time overruns in Hong Kong construction projects.

[8] Chan, A. P. C. (2001). Framework for Measuring Success of Construction Projects. Report 2001003-C-01: Value Alignment Process for Project Delivery. QUT, Australia.

[9] Chan, M., Coffey, V. \& Trigunarsyah, B. (2010). Steering towards pinnacle of success: the tenets in Australian construction contracting. In: CIB World Congress 2010: Building a better tomorrow, $10^{\text {th }}$ $-13^{\text {th }} 2010$, The Lowry, Salford Quays.

[10] Crosby, P. B. (1979). Quality is Free, New York: New American Library.

[11] Davis, K., Ledbetter, W, \& Burati, J., Jr. (1989). Measuring Design and Construction Quality Costs. Journal of Construction Engineering and Management, 115(3), 385-400

[12] DoF (2009). Capital of Works Management Framework, Guidance Note. Design and Development Process GN 2.1. Department of Finance, Dublin.

[13] Forsythe, P. (2015). Monitoring Customer Perceived Quality and Satisfaction during the construction process. COonstruction Economics and Building, 15(1), 19-42.

[14] Frimpong, Y., Oluwoye, J. \& Crawford, L. (2013). Causes and delay and cost overruns in construction ground water projects in developing countries; Ghana as a case study. International journal of Project Management, 21, 321-326.

[15] Handfield, R. B., Primo, M. \& de Oliveira, M. P. V. (2015). The role of effective relationship management in successful large oil and gas projects: Insights from procurement executives. Journal of Strategic Contracting and Negotiation, 1(1), 15-41.

[16] Jainendrakumar, T. D. (2015). Project Cost management for Project Managers based on PMBOK. A commentary. PM World Journal, IV (IV), 1-13.

[17] Lester, A. (2013). Project Management, Planning and Control: Managing Engineering, Construction and Manufacturing Projects to PMI, APM and BSI Standards, Sixth Edition, ButterworthHeinemann Imprint, 592 Pages.

[18] Lim, C. S. \& Mohamed, M. Z. (1999). Criteria of Project Success: An exploratory re-examination. International Journal of Project Management, 17(4), 243-248.

[19] Love, P. E. E., Tse, R. Y. C., \& Edwards, D. J. (2005). Time-cost relationships in Australian Building Construction Projects. Journal of Construction Engineering and Management, 131(2), 187194.

[20] Mirza, M. N., Pourzolfaghar, Z. \& Shahnazari, M. (2013). Significance of Scope in Project Success. Procedia Technology, 9, 722-729.

[21] Munns, A. K. \& Bjeirmi, B. F. (1996). The role of project management in achieving project success. International Journal of Project Management, 14(2), 81-97. 
Civil Engineering and Urban Planning: An International Journal (CiVEJ ) Vol.4, No.1, March 2017

[22] Nguyen, L. D., Ogunlana, S. O., \& Lan D. T. X (2004). A Study on project success factors in large construction projects in Vietnam. Engineering, Construction and Architectural Management, 11(6), 404-413.

[23] Odediran, S. J. \& Windapo, A. O. (2014). A systematic review of factors influencing the cost performance of building projects. In S. Laryea, \& E. Ibem (Eds). Proceedings of $8^{\text {th }}$ Construction Industry Development Board (CIDB) Prost Graduate Conference at University of the Witwaters and, Johannesburg, South Africa, Vol. III

[24] Olaoluwa P. (2013). Factors affecting cost of construction Projects in Nigeria (A Case study of roads and building firms in Akure). A Research project submitted to the department of Project Management Technology, Federal University of Technology, Akure, Nigeria.

[25] Owens, J., Burke, S., Krynovich, M. \& Mance, D. J. (2007). Project Cost control tools and techniques. [Online] URL: http://www.jasonowens.com/wpcontent/uploads/2009/12/ProjectCostControlTools_and_Techniques.pdf (It is not used for citation except for referencing because the copy right does not permit to do so).

[26] Pethkar, P. M. \& Birajdar, B. V. (2014). Literature Review on causes of delay in building construction projects. Journal of Information, Knowledge and research in civil engineering, 3(2), 217-220.

[27] PMBOK (1996). A Guide to the project management Body of knowledge. Project Management Institute, PA, USA

[28] PMI (2000). A Guide to the Project Management Body of Knowledge (PMBOK Guide).

[29] Prabhakar, G. P. (2008). What is Project Success: A Literature Review International Journal of Business and Management, 3(9), 3-10?

[30] Rad, P. F. \& Levin, G. (2002). The Advanced Project Management Office: A Comprehensive Look at Function and Implementation, CRC Press, 224 Pages.

[31] Rajabi, M. A. (n.d.). Chapter 7. Project Cost Management (PMBOK Guide). [Online] URL:http://www.marajabi.com/PMBOK/Chapter07.pdf Retrieved on May 28, 2016

[32] Rosenfeld, Y. (2009). Cost of quality versus cost of non-quality in construction: The crucial balance. Construction Management and Economics, 27(2), 107-117.

[33] Shenhar, A. J., Levy, O. \& Dvir, D. (1997). Mapping the Dimensions of Project Success. Project Management Journal, June Issue, 5-13.

[34] Shenhar, A. J., Dvir, D., Levy, O. \& Maltz, A. C. (2001). Project Success: A Multidimensional Strategic Concept. Long Range Planning, 34, 699-725.

[35] Song, S-H \& Lee, H-S (2004). Analysis and Utilization of Quality Cost in Construction Projects. In: Proceedings of $21^{\text {st }}$ International Symposium on Automatization and Robotics in Construction, Jeju, Korea.

[36] Spreng, R. \& Mackoy, R. D. (1996). AN Empirical Examination of the Antecedents of Perceived Service Quality and Satisfaction. Journal of Retailing, 72(2), 201-214.

[37] Steven, P. (2009-2011). Ten Contract for your next agile project, by Peter Stevens. [Online] URL:http://www.agilist.ch/wp-content/uploads/Peter-Stevens-Ten-Contracts-v001.pdf

[38] Takim, R. \& Ankintoye (2002). Performance Indicators for successful construction project performance. In: Greenwood, D (Ed.), $18^{\text {th }}$ Annual ARCOM Conference, September 2-4. Association of Research in Construction Management, 2, 545-555.

[39] Tomtsongas (2011). Scope, Time and Cost - Managing the Triple Constraint. [Online] URL: https://programsuccess.wordpress.com/2011/05/02/scope-time-and-cost-managing-the-tripleconstraint/ Retrieved on May 27, 2016.

[40] Tomtsongas, (2015). Beyond the Triple constraint - The project Hexagon. [Online] URL: https://programsuccess.wordpress.com/2015/05/01/beyond-the-triple-constraint-the-projecthexagon/ Retrieved on May 27, 2016.

[41] Tom, A, F. \& Paul, S. (2013). Project Monitoring and Control using Primavera. International Journal of Innovative Research in Science, Engineering and Technology, 2(3), 762, 771.

[42] Vasista, T.G.K. \& AlSudairi, M. A. S (2016). Determining project management success model: viewing through the application of CRASP methodology. Discovery: The International Journal, 52(243), 506-516. 